Original Paper

\title{
Penyuluhan Mengenai Kesehatan Reproduksi pada Komunitas Bajang Pejoeang Mataram
}

\author{
Rifana Cholidah ${ }^{*}$, Ida Ayu Eka Widiastuti ${ }^{1}$, Deasy Irawati ${ }^{1}$ \\ ${ }^{1}$ Fakultas Kedokteran Universitas Mataram, Indonesia
}

DOI: 10.29303/jpmpi.v2i2.367

Sitasi: Cholidah, R., Widiastuti, I. A. E., Irawati, D. (2019). Penyuluhan Mengenai Kesehatan Reproduksi pada Komunitas Bajang Pejoeang Mataram. Jurnal Pengabdian Magister Pendidikan IPA (JPMPI). (2) 2. pp. 111-113

*Corresponding Author: Rifina Cholidah, Fakultas Kedokteran Universitas Mataram, Indonesia; Email: rifana.cholidah@gmail.com

\begin{abstract}
Abstrak: Tujuan kegiatan pengabdian ini adalah untuk memberikan pengetahuan kepada Komunitas Bajang Pejoeang Mataram tentang: 1) perubahan fisik pada masa pubertas, terutama yang berkaitan dengan sistem reproduksi, 2) konsekuensi perkembangan sistem reproduksi, dan 3) cara menjaga kesehatan reproduksi. Penyuluhan kesehatan disampaikan oleh tim dosen beserta mahasiswa Fakultas Kedokteran Universitas Mataram. Materi disampaikan oleh tim dosen dan mahasiswa membawakan acara sebagai Master of Ceremony. Metode pelaksanaan berupa penyuluhan kesehatan mengenai kesehatan reproduksi pada Komunitas Bajang Pejoeang Mataram. Penyuluhan kesehatan reproduksi ini dihadiri oleh 24 peserta. Peserta sangat antusias, ditandai dengan banyaknya pertanyaan pada sesi diskusi setelah penyuluhan. Pada kegiatan ini disimpulkan bahwa masa remaja adalah salah satu masa terjadinya perkembangan paling pesat dalam perjalanan hidup manusia. Proses pematangan secara biologis umumnya mendahului kematangan psikososial pada remaja. Oleh karenanya diperlukan upaya edukasi terhadap remaja putra dan putri terkait kesehatan reproduksi untuk mencegah perilaku seksual di usia remaja.
\end{abstract}

Kata Kunci: Penyuluhan; Kesehatan Reproduksi; Komunitas.

\section{Pendahuluan}

Berdasarkan hasil Survei Penduduk Antar Sensus 2015, proporsi penduduk kelompok usia 1524 tahun adalah $16.5 \%$ atau sekitar 42 juta. Angka ini perkirakan akan semakin meningkat sampai dengan tahun 2030 kemudian akan mengalami penurunan. Hal ini berkaitan dengan transisi demografi di Indonesia (Lembaga Demografi FEB UI, 2017). Terkait hal tersebut, sampai tahun 2030, jumlah penduduk usia produktif akan meningkat dan hal ini dikenal sebagai bonus demografi. Untuk mengoptimalkan bonus demografi, diperlukan upaya untuk memastikan penduduk usia produktif tumbuh sehat dan cerdas sehingga benar-benar dapat produktif.

WHO mendefinisikan remaja sebagai individu yang berusia 10-19 tahun (WHO, n.d), sedangkan berdasarkan Peraturan Menteri Kesehatan RI tahun 2014, rentang usia remaja adalah 10-18 tahun. Berbeda dengan kedua definisi tadi, Badan Kependudukan dan Keluarga
Berencana Nasional (BKKBN) mendefinisikan remaja sebagai individu berusia 10-24 tahun yang belum menikah. Meskipun terdapat perbedaan rentang usia kelompok remaja dari berbagai otoritas, remaja diidentikkan dengan peralihan dari masa kanak-kanak ke dewasa.

Masa remaja adalah salah satu masa terjadinya perkembangan paling pesat dalam perjalanan hidup manusia. Proses pematangan secara biologis umumnya mendahului kematangan psikososial pada remaja. Perkembangan korteks pre-frontal yang bertanggung jawab terhadap fungsi eksekutif, pengambilan keputusan, organisasi, pengendalian impuls dan perencanaan masa depan terjadi lebih lambat dibandingkan dengan perkembangan sistem limbik yang bertanggung jawab terhadap kenikmatan dan pemrosesan ganjaran, respon emosional dan pengaturan tidur. Hal ini menyebabkan remaja cenderung tertarik untuk mengeksplorasi dan 
bereksperimen tanpa mempertimbangkan konsekuensinya (WHO, n.d).

Setiap tahun diperkirakan 21 juta remaja putri berusia 15-19 tahun dan 2 juta remaja putri di bawah usia 15 tahun hamil di negara berkembang. Sekitar 16 juta remaja putri berusia 15-19 tahun dan 2.5 juta remaja putri kurang dari 16 tahun melahirkan di negara berkembang. Kehamilan remaja merupakan permasalahan global yang terjadi di negara berpenghasilan tinggi, menengah dan rendah. Di seluruh dunia, kehamilan remaja lebih sering terjadi di komunitas yang terpinggirkan, umumnya karena kemiskinan, rendahnya tingkat pendidikan dan kesempatan kerja (WHO, 2018).

Kehamilan remaja merupakan kontributor utama kematian maternal dan kematian bayi dan siklus kemiskinan yang berhubungan dengan sakit penyakit dari satu generasi ke generasiberikutnya. Kehamilan dan komplikasi melahirkan adalah penyebab utama kematian remaja putri usia 15-19 tahun secara global. Hampir seluruhnya (99\%) terjadi di negara berpenghasilan rendah dan menengah. Hal ini terjadi karena ibu yang berusia remaja lebih berisiko mengalami eklamsia, endometritis puerpral dan infeksi sistemik dibandingkan dengan yang berusia 20-24 tahun. Selain itu, kehamilan remaja juga menyebabkan terjadinya 3.9 juta aborsi yang tidak aman setiap tahunnya. Secara emosional, psikologis dan sosial, kehamilan pada masa remaja juga menimbulkan masalah yang lebih besar (WHO, 2018).

Kehamilan dini dapat meningkatkan risiko bagi bayi yang dilahirkan maupun bagi si ibu. Pada negara berpenghasilan rendah dan menengah, bayibayi yang lahir dari ibu berusia kurang dari 20 tahun memiliki risiko lebih besar mengalami berat badan lahir rendah (BBLR), lahir prematur dan kondisi kesehatan lain yang serius. Hal ini tidak hanya merugikan pada jangka pendek, tetapi juga memiliki efek jangka panjang (WHO, 2018).

Data dari Survey Demografi dan Kesehatan Indonesia (SDKI) 2012 menunjukkan bahwa dua persen perempuan berusia 15-24 tahun di Indonesia telah melakukan hubungan seksual sebelum usia 15 tahun. Dari jumlah ini, sebagian besar merupakan perempuan yang tinggal di daerah pedesaan dan berpendidikan rendah (SD atau tidak tamat SD) (BKKBN, BPS, Kemenkes RI, ICF International, 2013). Berbagai studi yang meneliti perilaku seksual remaja di Indonesia menemukan angka yang bervariasi. Penelitian oleh Susanto et al
(2016) di Jawa Timur menemukan bahwa $43.7 \%$ remaja putri berusia 11-16 tahun di Indonesia telah menunjukkan perilaku aktif secara seksual (bersentuhan, berciuman, dan masturbasi) meskipun tidak ada partisipan perempuan maupun laki-laki yang melaporkan perilaku berhubungan seksual. Sementara penelitian oleh Suwarni et al. (2015) di Pontianak, menemukan bahwa remaja yang memiliki perilaku seksual di luar pernikahan sebanyak 9\% dan yang memiliki intensi untuk melakukan perilaku seksual premarital lebih besar lagi yaitu sebesar $19.2 \%$.

Sebagai upaya untuk meningkatkan kesehatan reproduksi remaja dan mencegah akibat buruk jangka panjangnya, WHO merekomendasikan agar remaja putri mendapatkan pendidikan seksualitas (WHO, 2018). Penelitian Susanto et al (2016) menunjukkan bahwa remaja putri yang kurang memiliki akses terhadap informasi mengenai perkembangan remaja dan penyalah gunaan zat lebih banyak yang menunjukkan perilaku seksual aktif. Sayangnya baru $52.53 \%$ puskesmas menyelenggarakan program kesehatan remaja di NTB, meskipun angka ini lebih baik dari rata-rata nasional yaitu $42.67 \%$ (Kemenkes RI, 2016). Oleh karena itu, diperlukan upaya edukasi terhadap remaja putra dan putri terkait kesehatan reproduksi untuk mencegah perilaku seksual di usia remaja.

\section{Metode Pelaksanaan}

Penyuluhan kesehatan disampaikan oleh tim dosen beserta mahasiswa Fakultas Kedokteran Universitas Mataram. Materi disampaikan oleh tim dosen dan mahasiswa membawakan acara sebagai Master of Ceremony. Metode pelaksanaan berupa penyuluhan kesehatan mengenai kesehatan reproduksi pada Komunitas Bajang Pejoeang Mataram. Penyuluhan diadakan pada hari Jumat tanggal 22 November 2019 di Jl. Airlangga 103A pukul 16.00 Wita. Penyuluhan kesehatan reproduksi ini dihadiri oleh 24 peserta. Peserta sangat antusias, ditandai dengan banyaknya pertanyaan pada sesi diskusi setelah penyuluhan.

\section{Hasil dan Pembahasan}

Kegiatan pengabdian ini berlangsung pada Jumat tanggal 22 November 2019 di Jl. Airlangga 
103A pukul 16.00 Wita. Kegiatan ini dihadiri oleh tim penyuluh Fakultas Kedokteran Unram beserta 2 orang mahasiswa sebagai Master of Ceremony. Acara dibuka sekitar pukul 16.15 wita. Peserta mulai memenuhi ruangan sekitar pukul 16.00. Materi penyuluhan disampaikan dengan menggunakan media Powerpoint, yang menjelaskan tentang tujuan pengabdian, perbedaan organ reproduksi wanita dan pria serta fungsi masing-masing organ reproduksi. Setelah penyampaian materi, diberikan kesempatan kepada peserta untuk bertanya dan peserta sangat antusias, terbukti dengan banyaknya peserta yang bertanya.

\section{Kesimpulan}

Masa remaja adalah salah satu masa terjadinya perkembangan paling pesat dalam perjalanan hidup manusia. Proses pematangan secara biologis umumnya mendahului kematangan psikososial pada remaja. Oleh karenanya diperlukan upaya edukasi terhadap remaja putra dan putri terkait kesehatan reproduksi untuk mencegah perilaku seksual di usia remaja. Penyuluhan kesehatan reproduksi yang dilakukan pada tanggal 22 November 2019 meningkatkan pengetahuan remaja di komunitas Bajang Pejoeang Mataram tentang kesehatan reproduksi wanita dan pria.

\section{Saran}

Diperlukan adanya penyuluhan lanjutan tentang cara pemeliharaan dalam menjaga kebersihan organ reproduksi dan dampak yang bisa diakibatkan apabila hal tersebut tidak terpenuhi.

\section{Daftar Pustaka}

BKKBN, BPS, Kemenkes RI, ICF International, 2013. Survey Demografi dan Kesehatan Indonesia 2012. Available from: http://chnrl.org/pelatihan-demografi/SDKI2012.pdf

Kementerian Kesehatan Republik Indonesia. 2016. Data dan informasi: profil kesehatan Indonesia 2016. Available from: http://www.depkes.go.id/resources/downlo ad/pusdatin/lainlain/Data\%20dan\%20Informasi\%20Keseha
tan\%20Profil $\% 20 \mathrm{Kesehatan} \% 20$ Indonesia $\% 202016 \% 20$ \%20\%20smaller\%20size\%20-\%20web.pdf Lembaga demografi FEB UI. 2017. Ringkasan studi: Prioritaskan kesehatan reproduksi remaja untuk menikmati bonus demografi. Available from: http://ldfebui.org/wpcontent/uploads/2017/08/BN-06-2017.pdf

Susanto, T. Rahmawati, I. Wuryaningsih, E.W., Saito, R., Syahrul, Kimura R.. 2016. Prevalence of factors related to active reproductive health behavior: a crosssectional study Indonesian adolescent. Epidemiology and Health, 38. Available from: http://e-epih.org/

Suwarni, L., Ismail, D., Prabandari, Y.S., Adiyanti, MG. 2015. Perceived Parental Monitoring on Adolescence Premarital Sexual Behavior in Pontianak City, Indonesia. International Journal of Public Health Science, 4 (3), pp. 211-219

WHO. n.d.Adolescent development. Available from:

http://www.who.int/maternal_child_adoles cent/topics/adolescence/development/en/

WHO, 2018. Adolescent pregnancy. Available from:

http://www.who.int/mediacentre/factsheets/ fs364/en/ 